\title{
Principles of Islamic Education Epistemology Tauhid Paradigm (Analysis of Thinking of Naquib Al-Attas)
}

\author{
Komaruddin Sassi \\ Faculty of Islamic Education, Islamic Institute of the Al-Qur'an Al-Ittifaqiah (IAIQI), Indralaya, Indonesia
}

\author{
Email address: \\ sassikomarudin@yahoo.com
}

\section{To cite this article:}

Komaruddin Sassi. Principles of Islamic Education Epistemology Tauhid Paradigm (Analysis of Thinking of Naquib Al-Attas). International Journal of Elementary Education. Vol. 10, No. 3, 2021, pp. 68-78. doi: 10.11648/j.ijeedu.20211003.14

Received: April 13, 2021; Accepted: April 28, 2021; Published: August 31, 2021

\begin{abstract}
This research explores the formulation of the principles of Islamic education in the monotheism paradigm initiated by Naquib al-Attas. The urgency of the problem in this paper is to reveal the results of the deep contemplation of Naquib alAttas on the practice of Islamic education nowadays which seems to have "run away" from the Islamic worldview (ru'yah alIsläm li al -Wujūd) which the author analyzed into five principles of the epistemology of Islamic education are based on monotheism. This library research uses qualitative data with primary sources, Prolegomena to The Metaphysics of Islam An Exposition of The Fundamental Elements of The Wordview of Islam (1995), and secondary sources from the works of Naguib al-Attas, including other people's work on their ideas and thoughts. This research result conclusions: First, the interpretation of monotheism is not limited to the theocentric dimension alone, but rather develops in the meaning in the anthropocentric dimension as well as the integration between the two in education and science so that the proper and true education term is $t a^{\prime} d i b$. Second, the implications of education as $t a^{\prime} d i b$, gave birth to the consequences of five principles of the epistemology of Islamic education in a monotheistic paradigm to be used as a reference in the system and process of civilized Islamic education.
\end{abstract}

Keywords: Epistemology, Islamic Education, Tauhid Paradigm

\section{Introduction}

Thought of Naquib al-Attas ${ }^{1}$ in mentioning the term education [2], it refers to the use of the terms $a d a b$ and $t a^{\prime} d i b$ as appropriate and correct terms. The formulation of the epistemological principles of Islamic education in the tauhid paradigm in this paper is a consequence of the conceptions of $a d a b$ and $t a^{\prime} d i b$ in Islamic education itself. Because $a d a b$ is a prerequisite for science and education, with $a d a b$ encouraging justice and wisdom as a gift from Allah, while $t a^{\prime} d i b$ is an epistemology for clarifying Islamic education with a tauhid paradigm.

Researcher's analysis of the primary data of Naquib's works both in English and Malay, there are at least seven

1 Next written Naquib. According to his private collection, the official genealogy of the Naguib al-Attas family indicates that he was the 37th descendant of the Prophet Muhammad. See Wan Mohd Wan Daud, Philosophy and Practice of Islamic Education Syed Muhammad Naquib al-Attas, (Bandung: Mizan, 1991), p. 45 . essential elements which are fundamental as key concepts that are referred to in order to describe and formulate a definition of Islamic education. The seven essential and basic elements, [3] namely: the concept of religion $(d \bar{i} n)$, the concept of man (insān), the concept of science ('ilm and ma'rifah), the concept of policy (wisdom), the concept of justice ('adl), the concept of charity ('amal as adab), and the concept of university (kulliyyah-jami' $a h){ }^{2}$

Based on the seven fundamental essential elements, which are the main essential elements and must be present in the conception of Islamic education. In turn, Naquib develops these essential elements into the elaboration of key concepts as the basic vocabulary of the conceptual system of Islamic education so that it can give birth to a more appropriate

2 Naquib al-Attas, The Concept of Education in Islam: A Framework for the Development of the Philosophy of Islamic Education, trans. Haidar Baqir, from the original title The Concept of Education in Islam: A Framework for an Islamic Philosophy of Education. (Bandung: Mizan, 1984) cet, 1, p. 8. See also Naquib alAttas, Islam and Secularism, (Bandung: Pustaka Salman ITB, 1981), trans. Karsidjo Djojosuwarno, cet, 1, p. 233. 
conception of education as an educational term.

As for what is meant by the basic vocabulary of the conceptual system is interwoven Key concepts that support the birth of the concept of education in Islam as adab, [4] namely: the concept of meaning/ma'na (معنى), science (على)), justice (عدل), wisdom (حكمة), action (عمل), truth or accuracy with respect to true and real (حق) (نطق), reason (نف) (عقل), heart (قلب), mind and intellect (عقل), a hierarchical order in

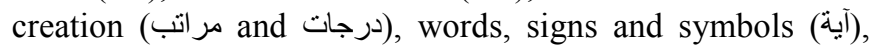
and interpretation (تفرير and تفابر).

Starting from the integral interwoven of the aforementioned key concepts, it seems that it gave birth to a conception of education with the term "ta'dib." ${ }^{4}$ Thus the birth of the term $t a^{\prime} d i b$ as a term of education in Islam is inseparable from the links that lie in these key concepts, [7] where the main key concept is found in the concept of $a d a b$ as a term of education, which is truly educational and which is uniquely Islamic.

\section{Discussion}

\subsection{Epistemology Principles of Islamic Education Paradigm Tauhid Naquib}

The birth of the epistemology of tauhid in Islamic education, is essentially based on the initial idea of the concept of $a d a b$ and earlier itself. Because, these two conceptions ( $a d a b$ and $\left.t a^{\prime} d i b\right)$ are closely related to one another. On the one hand manners and $t a^{\prime} d i b$ apart from being the correct conception of Islamic education, on the other hand also contain the meaning as the epistemology of Islamic education with the paradigm of tauhid. Even in turn, it will also contain the meaning of the goals to be achieved from the results of Islamic education itself.

The epistemological formulation of monotheism referred to by Naquib is a scientific way of working by uniting sensory, spiritual, intellectual and intuitive elements in totality to obtain knowledge. At the same time also by uniting various existing epistemologies, which have been used by theologians, philosophers and metaphysicists, without exaggerating a particular epistemology. As between the empirical and rational methods, between deductive and inductive patterns, between subjective and objective, and others. ${ }^{5}$

The main sources that are used as references and references to Naquib are basic values based on the al-Qur'ān and al-Sunnah as

3 Ibid., h. 52-53. See Naquib al-Attas, Islam and Philosophy of Science, trans. Saiful Muzani, from the original title Islam and the Philosophy of Science. (Bandung: Mizan, 1995), cet. 1, h. 41-45; also Naquib al-Attas, Islam and Secularism, p. 45-46.

4 Ibid., h. 60. For Naquib al-Attas, education is the sowing and cultivation of manners in a person, as a good human being who fully realizes his responsibility to the Righteous God, who understands and fulfills justice for himself, and others in his society, and continues trying to improve every aspect of him to perfection as a civilized human. And this kind of process is what is called ta'dib. See also, Syed Muhammad Naquib al-Attas, Treatise for Muslims, (Kuala Lumpur: ISTAC, 2001), p. 54.

5 Syed Muhammad Naquib al-Attas, Prolegomena to The Metaphysics of Islam An Exposition of The Fundamental Elements of The Worldview of Islam, (Kuala Lumpur, Malaysia: ISTAC, 1995), p. 3-96-97. well as the traditions of previous Muslim scholars ${ }^{6}$ which is combined with theology, syari'ah, philosophy, Islamic metaphysics (at-tsashawwüf), and intuition. ${ }^{7}$ Not based on the epistemology introduced by the Western philosophical tradition of science such as materialism or idealism which is supported by approaches such as empiricism, rationalism, realism, nominalism, pragmatism, positivism, logical positivism, criticism, which have sunk over the centuries, giving rise to one replacing the other until today. ${ }^{8}$

The following are some of the verses of the al-Qur'ān that Naquib referred to in formulating the epistemological principles of tauhid in Islamic education, [1] namely:

"Every soul has a taste of death.",

"The believers are siblings to one another."

"All will be destroyed except Allah."11

"There is nothing like Him.",12

"Only knowledgeable people among His servants who fear Allah." 13

"We do not create jinn and humans except for worship."14

"Indeed, humans are a loss except those who believe and do good deeds and advise one another in truth and patience." 15

"Surely Allah will not change the fate of a people so that people change their own destiny." 16

All of the basic values contained in the aforementioned verses of the al-Qur'ān were developed and used by Naquib as the main basis in formulating the epistemological principles of tauhid in science and education which are characterized by Islam.

From the analysis that the author can trace to the various works of Naquib, there are at least five formulations of the epistemological principles of tauhid in Islamic education, namely as follows: First, the values of tauhid epistemology in al-Qur'ān dimension are diametrically not speculative. Second, put forward the significance of spiritual substance. Third, the epistemological values of tauhid are the unification of religious and scientific values. Fourth, minimizing the problematic dichotomy between objective and subjective science. Fifth, it has the potential to give birth to an exposition of scientific knowledge in the Qur'àn. In turn, hopefully the epistemological principles of tauhid Islamic education in the tauhid paradigm can contribute in the form of thought products in the discourse of educational development in Indonesia.

6 Ibid., h. 86, 197 and 201. See also Naquib al-Attas, Concept of Education, p. 89-95; Wan Mohd Nor Wan Daud, Philosophyand Practice of Islamic Education at SMNA, p. 299-230.

7 Naquib al-Attas, Concept of Education, p. 89-90. See also Naquib al-Attas, Islam and Philosophy, p. 34-40.

8 Ibid., h. 2.

9 QS. Ali 'Imrān: 185, QS. al-Anbiyā ': 35, and QS. al-'Ankabūt: 57. 10 QS. al-Hujurāt: 10.

11 QS. al-Rahmān: 26.

12 QS. al-Syūrā: 11.

13 QS. Fāthir: 28.

14 QS. al-Dzāriyāt: 56

15 QS. al-'Ashr: 2.

16 QS. al-Ra'd: 11 


\subsection{The Five Principles of Islamic Education Paradigm Tauhid Naquib}

The following describes the five principles of Islamic education paradigm tauhid Naquib.

\subsubsection{The Values of Monotheistic Epistemology with the Dimensions of the Qur'ān Are Diametrically Not Speculative}

Judging from the discourse of the development of science that has developed in the entire history of Islamic culture, religion and intellectuals. According to Naquib for Islam there is no special era, as experienced by the West which is marked by the domination of thought systems based on the philosophical view of secular science. ${ }^{17}$

It is different from the Islamic world view that apart from acknowledging the development of knowledge that occurs through the senses and sensory experience and can be done and not underestimated. However, it must also be admitted that this is not limited to the power of reason alone, but in Islam it is also seen that the attainment of science essentially involves spiritual aspects, especially those originating from revelation (al-Qur'ān) and are justified by religion, and are strengthened. by intellectually and intuitively. ${ }^{18}$

That is the importance of the spiritual aspect with the various elements in it to obtain knowledge and education. In fact, metaphysically the spiritual aspect is believed to be better and very prioritized, [5] because with the epistemology of unification (tauhid) of sensory, spiritual, intellectual and intuitive elements in totality in analyzing ideas in the attainment of science and education, of course it will more able to lead to the attainment of a science that is correct and correct. That is why, with the unification of the various elements that exist in the human soul, it is a very important way to be applied in educational practice. ${ }^{19}$

As for the development of science and education today, [10] Naquib argues that it has been infiltrated by secular Western philosophy of science and applied in education and knowledge systems and processes. As a result, the process of education and knowledge neglects aspects of spiritual values, is changed by speculative science, so that it loses the most

17 Naquib al-Attas, Prolegomena, p. 2-5. Namely the view of materialism or idealism which is supported by epistemological approaches and positions, such as empiricism, rationalism, realism, nominalism, pragmatism, positivism, logic positivism, and criticism, which have moved back and forth from century to century and have appeared one after another to the present era. See also Naquib al-Attas, Islam and Philosophy, p. 36-39; Wan Daud, Philosophy and Practice, p. 294.

18 Naquib al-Attas, Islam and Philosophy, 38 and 40. In terms of intuition, when reason and experience are unable to give coherent meaning to specific problems, new meaning can be achieved through intuition, because intuition is capable of synthesizing things that are seen separately by reason and by experience without being able to be combined into a coherent whole. Therefore intuition is ultimately closely related to authority. And the highest authority in the view of Islamic science and philosophy comes from the Qur'ān and the Sunnah of the Prophet, including the holy person of the Prophet. These two supreme source authorities are not only in the sense of conveying truth, but also shaping truth.

19 Naquib al-Attas, Prolegomena, p. 3. The epistemology of the unification of these important elements is part of one of the aspects that is often said by Naquib with the epistemology of tauhid in science and education. important side of the Islamic world view which has been standardized in a belief system (tauhid) which is clearly in conflict with the sophists. ${ }^{20}$

Regarding the conditions as stated above, it is very unfortunate to occur today, [15] because it was believed by past Muslim intellectuals, and in the religious tradition that all knowledge of reality and truth, especially in the fields of knowledge and education, initially emerged through intuition. ${ }^{21}$ However, in the process of exercising intuition, it is not merely what applies to the level of discursive reason, which is physical, and which is only based on sense experience. But with the intellectual and spiritual powers as well as the powers referred to by the spiritual entity (allatîfah rühaniyyah) including the mind, heart, soul, and self (nafs). ${ }^{22}$

Thus, it can be understood that intuitive activities carried out to acquire knowledge and education involve all rational, imaginal, and empirical existence in totality, at a combination of physical and spiritual levels, but still refer to spiritual entities (al-latĩfah rūhaniyyah).

Therefore, in relation to the above context, Naquib in Wan Daud argues that the medium of tsashawwuf is one aspect of the development of spiritual entities (al-latīfah rühaniyah), and is very important in gaining knowledge and education. ${ }^{23}$ A similar opinion regarding the urgency of Sufism, [9] as a medium to gain deeper awareness of the fall of God and in obtaining knowledge, was also expressed by Ibn Khaldun, in his famous work, Muqaddimah (Introduction to World History) placing Sufism in a global Islamic perspective. ${ }^{24}$

20 Ibid., h. 87, 139. Naquib al-Attas divides the sophists into three groups. The first is called the al-la adriyyah or gnostic group, because they always say they don't know ( $l \bar{a} a d r \bar{\imath}$, i.e. 'I don't know') or are always doubtful about the existence of something so as to deny the posibility of science. Such a person, in turn, will also doubt his attitude of doubting the existence of everything. The second is the al-'indiyyah group, namely those who are always subjective. This group accepts the posibility of science and truth, but rejects the objectivity of science and truth. For them, the objectivity of science and truth is subjective (indī, that is, 'I think'), depending on the opinion of each. The third group, is al-inädiyyah, namely those who are stubborn, which denies the reality of everything (haqa'iq al-asyya') and considers it a fantasy (auham) and mere delusion. In this third group there are similarities to the second group. See also Wan Daud, Philosophy and Practice, p. 321.

21 Ibid., h. 177. See also Ibn Sina, Kitab An-Najaf, (Dar al-Afaq al-Jadidah, Beirut, 1985), p. 206.

22 Ibid., h. 148. The spiritual entity (al-latīfah rūhaniyyah) is a spiritual tenderness, is an object that is created, but is eternal, it is not measured in terms of space and time or quantity, it is self-awareness and the locus of understandings, and the means knowing it is only through reason and by observing the activities which derive from it.

$23 . .$. through Sufism, it has aroused a spirit of intellectualism and rationalism that did not exist in the pre-Islamic era... fundamentally shifted the world view of the Malay-Indonesian people, changed it from a fragile mythological world... to the world of intellectualism, the world of reason, and orderly world; Sufism emphasizes belief in God whose power is governed by wisdom (wisdom), and His Will works according to reason. Islam also emphasizes that man is a symbol of creation, whose essence is rationality that is the link between himself and Reality. Finally, this spirit prepares the Malay-Indonesian nation, in several ways, to enter the modern world that will come. Wan Daud, Philosophy and Practice, p. 321.

24 Ibnu Khaldun, Muqaddimah, (Jakarta: Pustaka Firdaus, 1986), trans. Ahmadie Thoha, p. 521. Sufism is a form of knowledge about religious law (syari'at) that arises in Islam, as a way of truth and noble character. Sufism is based on strict 
It can be understood that Sufism is a medium for controlling the mind (soul) and actions that encourage doing something towards God's will, not merely paying attention to humans and nature. In Sufism, it does not separate thought and action, instead these two aspects (as an entity for every human being) must be developed simultaneously, but still refer to God's will. The attitude of patronizing the aspect of Sufism seems to be reflected in some of the thoughts of Muslim scholars. So that it can be influenced by classical Greek thought, [11] such as Socrates and Plato, ${ }^{25}$ where his thinking emphasizes speculative thinking by denying the authority of revelation and intuitive principles. ${ }^{26}$

From the above explanation, it can be understood that the orientation of a truth in science is very much determined by the correct and correct epistemology in the educational process. In addition, it must also have relevance to the source of the origin of knowledge in the Islamic worldview which is centered on the existence of absolute reality, namely Allah SWT., So that a true truth can be found (haqq).

\subsubsection{Prioritizing the Significance of Spiritual Substances}

In essence, the discussion of this second principle is still closely related to the first principle. In this second principle of monotheistic epistemology, Naquib examines it from the relationship between the psychological aspects of the human soul and the validity of the channels for obtaining knowledge. Based on the Islamic world view, it is believed that there is a high relationship between the psychological aspects of the human soul and the validity of the channels for obtaining knowledge. This is because the human soul is a single reality with four different states (ahwal/modes), such as intellect ('aql), soul (nafs/soul), heart (qalb/ heart), and spirit (spirit) respectively. involved in human activities. ${ }^{27}$ This conception is in accordance with the Qur'ān, especially in the QS. al-Mu'minūn:12, ${ }^{28}$ and al-Hijr: $26-29 .^{29}$

piety, full trust in Allah, harmonizing thoughts and actions that are in line with God's will. So that it is as if all the temptations of the world, physical delights, wealth and honor are all sought by everyone, and instead, in a time of solitude, away from the busyness of the world, use the time for prayer (remembrance). This kind of thing was commonplace among the companions of the prophet and first generation Muslims.

25 Wan Daud, Philosophy and Practice, p. 352-353. See also Murtadha Muttahari, Introduction to Islamic Epistemology, (Jakarta: Shadra Press, 2010), p. 73. Plato in referring to the source of science only believes through reason by using a dialectical epistemology through an argumentative pattern of reason (ratio) alone. So that according to him, everything that the ratio cannot reach is not an object of knowledge.

26 Naquib al-Attas, Prolegomena, p. 139-140. Naquib was very surprised by the statement of Abdus Salam (d. 1996), a Nobel Prize winner, who stated that he (Abdus Salam) could not bring God and religion in his scientific studies. Whereas earlier Muslim sages and theologians, through intuitive experience - although without the help of modern scientific tools - were able to understand the true nature of the universe which was created because they understood God, and applied theological and spiritual principles.

27 Ibid., h. 144-145, and 148.

28 Meaning: "And indeed, We have created man from the essence (comes) of the ground." Surah al-Mukminun: 12.

29 Meaning: "And indeed, We created man (Adam) from dry clay from the black mud which was given a shape. And We have created the jinn before (Adam) from a very hot fire. And (remember), when your Lord said to the angels, Truly, I will create a man from dry clay from black mud which is given shape. So when I have
According to Naquib by interpreting the verses of alQur'ān surah al-Mu'minūn: 12 and surah al-Hijr: 26-29, it shows that humans have two dual characteristics, consisting of body and soul, as well as physical and spiritual beings (spiritual) likewise with the nature of His compassion for humans. Allah Most High, gave the teaching of names (alAsma') about everything. ${ }^{30}$ On that basis, all the potentials possessed by humans and also the knowledge obtained by humans are initially solely by the grace of Allah SWT, including the soul that exists in humans themselves. ${ }^{31}$

After all, it is believed for Muslims, that the provision of knowledge about the soul is only given by Allah SWT, to humans in a small and limited degree, as stated in the alQur'an surah Ban̄̄ Isrāīl:85. ${ }^{32}$ So that it gives an understanding that the essence of science is limited, and not neutral. However, through the knowledge that Allah-which is little and limited-to humans. Humans can still come to the knowledge of God (al-ma'rifah) and the object of devotion (al-Ilāh). ${ }^{33}$ This is especially so if humans are able to mobilize their mental powers (namely, the four single realities, as stated above) optimally and in totality on the principles of justice and wisdom. Besides being able to subdue the animal soul that is inherent in itself under the control of the rational soul.

Thus, it can be understood that what is meant by the soul as a single reality with four different names is sometimes also called a spiritual entity or spiritual substance, and is also sometimes called the soul of al-nafs an-näthiqah. All of these terms refer to the same unity of meaning, as the highest center of human existence. Meanwhile, the other dimensions are al-nafs al-nabātiyyah (vegetative soul) and al-nafs alhayawāniyyah (animal soul). ${ }^{34}$

Starting from the above understanding, it shows that the confusion and injustice that occur today are originated from

perfected (the incident), and I have breathed the spirit (My creation) into it, then you submit to him by prostrate." Surah al-Hijr: 26-29.

30 QS. al-Baqārah: 31.

31 QS. Hā Mīm / Fussilat: 53.

32 QS. Banī Isrāīl: 85.

33 QS. Ali Imrān: 81; QS. al-A'rāf: 172.

34 Naquib al-Attas, Prolegomena, p. 149. Naquib's affirmation regarding the psychology of the human soul, namely: First, it is reason which is sometimes called the intellect ('aql) which is cognitive in nature. Second, is the soul (nafs/soul) is empirical. Third, is the heart (qalb/heart) which is intuitive. Fourth, is the spirit (spirit) which is spiritual in nature. These four spiritual substances (alnafs an-nāthiqah) often collide with animal nature (al-hayawāniyyah) which causes neglect (nisyān), resulting in confusion and tyranny. The single reality of the human soul consists of three parts, namely: the vegetative soul (alnabātiyyah), the animal soul (al-hayawāniyyah), and the rational soul (alnātiqah), with five external and internal senses. As for the external senses is the feeling for feeling, feeling, smelling, see, and hear. Whereas what is part of the internal soul is: First, common sense (al-his al-musytarak) which functions to collect data in a general sensing process of perception. Second, representation (alkhayaliyyah) which functions to store images. Third, estimation (al-wahmiyyah) functions to assess imaginatively and instinctively without intellectual analysis and memory assistance. Fourth, retentive and recollective (al-hafizah and aldhakirah) which function to store and collect forms and meanings so that the faculty of estimation act. Fifth, imagination (al-mutakhayyilah) which has two functions, namely sensory imagination (mutakhayyil) which is responsible for human technical and artistic products. 
science itself which has lost its purpose, and this is a product of skepticism that puts doubt and speculation on a par with scientific methodology, and makes it a valid epistemology in looking for the truth. ${ }^{35}$ That is why obtaining the correct and correct knowledge cannot be separated from the source and owner of that knowledge, namely revelation that comes from Allah SWT. On the basis of this context, it indicates that science is not value-free (neutral), because it may be that a science is possessed by form and content disguised as knowledge.

Thus, it can be stated that knowledge originates from the al-Qur'ān, and the arrival of that knowledge into one's rational soul (al-nafs al-nātiqah) depends on one's spiritual, intellectual and ethical qualities. Therefore, the forms of the objects of something new can be said to be knowledge in one's self, if the essence of those objects is in the brain, what is outside the brain, is only the object of knowledge (alma'lumāt). ${ }^{36}$

The strength and depth of the rational soul (al-nafs alnätiqah) combined with physical strength to perceive various scientific objects like that, which are indispensable in the attainment of correct and correct knowledge. This is due to the nature (shifah) of the nature of science itself which refers psychologically to the rational soul (al-nafs al-nātiqah). On the other hand, when the soul understands the meaning of an object of knowledge, that is when a person who knows can put that object correctly and relates it appropriately to the key elements in his view of life. On the basis of the conception mentioned above, human cognition is essentially subjective and objective, in harmony between theory and practice. ${ }^{37}$

Furthermore, Naquib reminded the view that science is in the brain or in the soul, this should not lead to subjectivism, because God, who is the Real Source of Knowledge, - who is free from doubt and confusion - is objective, namely BeingIt does not depend on human imagination, but is in line with the meaning of the content of the al-Qur'an which states it as knowledge of al-yaqīn, ${ }^{38}$ 'ain al-yaqīn, ${ }^{39}$ and haqq al-yaqin. ${ }^{40}$

35 Naquib al-Attas, Islam and Secularism, p. 210.

36 Wan Daud, Philosophy and Practice, p. 212. Traditional Muslims have long realized that knowledge is not in books, but in the chest, namely shadr, the place of consciousness (al-'ilmu fi al-shudūr la fi al-suthur).

37 Naquib al-Attas, Prolegomena, p. 96-98. Human cognition is subjective because the human soul is involved in interpreting the object of knowledge, and objective because the interpretation of the soul is not merely an imaginary glimpse of an object of knowledge that actually exists independently of the human brain. The truth of such a particular object of knowledge is the same for everyone even though the degrees of certainty may differ.

38 Ibid., h. 86. The level of certainty of knowledge 'ilm al-yaqin (QS. al-Takātsur: 5), namely, the certainty that comes from drawing conclusions, either deductively or inductively.

39 Ibid., h. 86. The level of certainty of knowledge 'ain al-yaqīn (QS. al-Takātsur: 7 ), namely, the certainty that comes from direct vision.

40 Ibid., h. 87. The level of certainty of knowledge of haqq al-yaqin (QS. AlHaqqah: 51 and QS. Al-Wāqi'ah: 95) that is, certainty that comes from direct experience. The three levels of certainty of knowledge above relate to truth, whether tangible or hidden, empirical or transcendental, and certain and hidden knowledge has the same certainty power as what can be seen (visible). These levels of certainty are also related to what is felt by the organ of spiritual cognition, namely the heart (al-qalb), and refer to knowledge as belief and faith (faith).
In this connection, [8] al-Ghazali illustrates what is meant by knowledge of al-yaqin and 'ain al-yaqin is knowledge of al-yaqin, which is the science of death and the realm of the grave for the living, because they know that people who die are buried but they not knowing their state in it. Meanwhile, 'ain al-yaqin is knowledge for people who have died, because they are the ones who witness the state of the grave, sometimes in the form of one of the gardens of heaven or one of the abys of hell. In short, the science of al-yaqin is the knowledge of the end of the world or witnessing the events of the Day of Judgment and its awesomeness. Meanwhile,'ain al-yaqin knowledge of heaven and hell or seeing heaven and hell directly. ${ }^{41}$

It can be taken an understanding from the point of view of Naquib and al-Ghazali above, that the essence of science is indeed in the brain or in the soul. The human brain or soul is the dwelling place for knowledge. Thus, the logical consequence is that Muslims who have knowledge in their brains tend to think well and understand their own views of life correctly and correctly.

The highest point is to implement the epistemology of tauhid in education by motivating the science claimants by continuing to develop the rational soul and subjecting the animal soul to the control of the rational soul which is the spiritual substance which is the place for intuition. On the other hand, if what happens, the rational soul is subordinated to the domination of the animal soul, then such a state can humiliate humans to a lower state, even from a lower one.

\subsubsection{The Epistemological Values of Tauhid Are Unification Between Religious and Scientific}

Science is not born by itself, it originates from an investigation and research on various objects that lie in Allah's Revelation and the universe - as the second ledger the source of the object of science. Without an investigation and research, of course it is very possible not to acquire knowledge. This requires the existence of an epistemology that is correct and correct to obtain this knowledge.

The Muslim intellectual tradition in the past did not only use one epistemology or two epistemologies in the investigation to obtain correct and correct knowledge, but instead used various epistemologies of science in research. ${ }^{42}$ That is why, the unification of these various epistemologies is termed by Naquib with the epistemology of tawhid knowledge, because it unites various epistemologies that exist in one unified whole, besides reflecting the characteristics of religious traditions and Muslim intellectual traditions.

41 Al-Ghazali, Revealing the Secret of Qalbu: Efforts to Get Closer to the Presence of Who Knows All the Unseen, (Bandung: Nansa Aulia, 2008), cet. I, h. 420-421., Trans. Bahrul Abubakar, From the original title Mukāsyafatul Qulüb alMuqarribu ila 'Allāmil Ghuyūb fi' Ilmi al-Tsashawwūf.

42 Naquib al-Attas, Prolegomena, p. 3. In fact, all representations of the Islamic tradition in the investigation of various sciences have applied various epistemologies, such as religious and scientific, empirical and rational, deductive and inductive, subjective and objective without making one epistemology more dominant than the other. So that all the epistemologies they use are what Naquib al-Attas calls the epistemology of unification (tauhid). 
One application of the epistemology of tauhid that has been practiced by Naquib is when conducting research on the process of Islamization of science in the Malay Islamic world, namely... in carrying out the process of Islamization of knowledge that occurs in the Malay Islamic world as a universal historical phenomenon, similar to someone who cannot understand Islam in the Malay world, except after understanding Islam itself as a religion and civilization. Thus, the point is that the process of Islamization that occurred at the time of the Prophet and his companions was also carried out through the new Arabic-Islamic language. This is because according to Naquib that all the key terms and concepts used in intellectual and spiritual discourse in Malay-which are also non-Arabic languages from the 15th century to the present, come from Arabic-Islam. ${ }^{43}$

Actually this monotheistic epistemology has been widely used by Sufists, philosophers, and theologians in studying science. In this context, Naquib said, it should be clear that the many Sufistic, philosophical and theological elements in religion should be preceded by a general acceptance of religion based on faith and external expressions of this faith with charity protected by a strong legal basis. ${ }^{44}$ From this, it appears that the pattern of deductive and inductive approaches and the union of the two can be said to be a characteristic part of Naquib's thinking about the process of Islamization. $^{45}$

A scientific approach that uses a deductive pattern means taking a number of whole and then developing it. This approach is in line with QS. Al-Kahfi: $109,{ }^{46}$ which states that human knowledge is only a drop from the ocean of truth of Allah's knowledge. as an epistemology, this deductive approach contains the meaning of a theory that is general in nature, verified, then carried out in some special cases (particular). So that the deductive approach to al-Qur'ān, [18] is carried out by interpreting the verses of the al-Qur'ān and then developing it scientifically to gain an understanding of its applicability in a particular discipline. ${ }^{47}$

The inductive approach only tries to connect the findings

43 Naquib al-Attas, Concept of Education, p. 15-16. Among the terms are: ruh $(r \bar{u} h)$, intellect ('aql), heart (qalb), lust (nafs), understand (fahm), body, jisim (jism), physical (jusmani), Jauhar (Jauhar), juzu' (juz), lecture (kulliyyah), inspiration (inspiration), awareness (from Arabic shadr = chest), thought (fikr), dhikr (dzikir), knowledge ('ilm), sure (yaqin), syak (syakk), zann (zhann), ignorance ( $j a h l$ ), nature ('nature), experience (from Arabic' nature), cause (sabab), musabab (musabbab), effect ('aqibah), wisdom (wisdom), adab (adab), dignity (marātib), degree (darājah), maudu' (maudhu'), fair ('adl), zalim (zhulm), ma'rifat (ma'rifah), ta'rif (ta'rif), essence (haqīqah), tsabit (tsabit), kalam (qalam), paper (qirthash), syarah (syarh), language (bahts), law, judge, court (from Arabic: $h u k m)$, ustad (ustadz), student ( students), da'wat (da'wah), date (tärikh), age (age), beginning (awwal), end (end), history (syajarah), century, time (waqt), moment $\left(s \bar{a}^{\prime} a h\right)$, seat $(k u r s \bar{l})$, and many more. See also Wan Daud, Philosophy and Practice, p. 322.

44 Naquib al-Attas, Prolegomena, p. 192.

45 Ibid., h. 192. See Wan Daud, Philosophy and Practice, p. 324

46 QS. al-Kahfi: 109. Meaning: "Say (Muhammad), if the sea becomes ink for (writing) the words of my God, then the sea will certainly end before the completion of (writing) the sentences of my God, even though We bring additional. that much (anyway)."

47 Nasaruddin Umar, Method of Interpretation of the Verses of Science and Social, in Andi Rosadisastra, (Jakarta: Amzah. 2012), cet. III, p. x-xi. from the research results with the verses of the al-Qur'an that deserve to be symbols. Thus, the answers to the research results already exist, then what is sought is a series of questions, namely the statement of the appropriate symbol among the available questions. Usually this pattern of inductive approaches tends to be developed in a 'secular' manner so as to produce scientific and technological discoveries. $^{48}$

Starting from the above thought, it seems clear that the earlier Muslim intellectuals, in carrying out their investigation of various sciences, used various epistemologies. Especially when comparing the deductive and inductive patterns, it appears that the dominant tendency of earlier Muslim intellectuals to apply to deductive patterns, realizing that human science is very little, especially without the gift of Allah SWT. That is why, for Naquib, he does not consider one epistemology to have a higher dominance than other epistemologies, and even be united into a monotheistic epistemology.

The epistemology of tauhid in knowledge and education, in the view of the Islamic world, is believed to be better for obtaining knowledge and education. Because the essence of all knowledge is the gift and grace of Allah SWT., and by applying the epistemology of tawhid in knowledge and education, it means reflecting a pattern of approach that breathes religion $(d \bar{i} n)$.

\subsubsection{Minimizing the Problems of the Subjective and Objective Science Dichotomy}

Until now, it is recognized that there are different and fundamental views in reviewing a reality and truth and its relationship with facts between the review of modern Western philosophy of science and the Islamic world view or the philosophy of Islamic science. Understanding what is referred to by these two different views has a considerable influence on understanding the meaning of science and epistemological processes, and continues to penetrate other aspects.

The existence of different views of different philosophies of science is quite sharp, creating confusion and mistakes in all fields, especially in the problematics of science. As is well known, the tendency in the modern philosophy of science views the sources and epistemology of science as oriented to phenomena and empirical realities solely. ${ }^{49}$ Meanwhile, in Islamic philosophy of science, the source and epistemology of science is ultimately through reason and intuitiveness by referring to divine revelation and the sunnah of the Prophet. ${ }^{50}$

\section{Ibid., p. x.}

49 Naquib al-Attas, Prolegomena, p. 2, and 114. See also Naquib al-Attas, Islam and Philosophy, p. 27-28.

$50 \mathrm{Ibid}$., p. 118 and 121. In the Islamic view, it is believed that knowledge comes from God and is obtained through reliable sense channels based on authority, common sense and intuition. The highest authority is the holy book of al-Qur'ān and as-Sunnah of the Prophet including the holy person of the Prophet who is holy (holy). Both are the authority of the source of knowledge which is not only the truth, but also the authority formed over the higher levels of intellectual and spiritual cognition and transcendental experience, which is not reduced to the normal level of thought and experience. 
The orientation of Western philosophy of science in science tends to focus on aspects that are only concrete and which can be observed (empirical). Meanwhile, the Islamic perspective believes that the orientation of science can be both concrete and abstract, including the problem of knowledge of the spirit, heart, soul, and self (nafs), because the object of knowledge is the human being himself. ${ }^{51}$

As for the Islamic world view, the sources and epistemology of science, according to Naquib, are: First, the physical and mental senses, namely the physical senses which include; body taste, smell, tongue taste, sight, and hearer. While the inner senses include; perceiving sense images and their meanings, unifying or separating, perceiving (conceptualizing) ideas, storing the results of perception, and carrying out intellect, in general the inner senses are; representation, estimation, memory and recall, and imagination. Second, reason and intuition, the source and method of this second knowledge, imply that the objects of knowledge are not limited to what can be seen by reason, but also through the inner eye. Third, authority, namely the sources and methods of science that have the correct report. ${ }^{52}$

Thus, it can be understood that the scope of the sources and methods of science in the Islamic worldview is broader and more comprehensive, and also primarily refers to the source of the origin of knowledge, namely the revelation and the person of the Holy Prophet, as well as the authority of both. On that basis for Naquib a science is essentially a word or symbol ( $\bar{a} y a h)$ of God, therefore to know it as it really is is to know what it refers to, what it symbolizes, what its meaning is. If it considers a word as if it has its own independent reality, then it is no longer a sign or symbol because its existence is to denote itself. 53

That reality only belongs to Allah SWT. so that what is studied as objects of knowledge is only symbols ( $\bar{a} y a h)$, this is in accordance with the Islamic concept called truth (haqq). ${ }^{54}$ And as the opposite is falsehood, failure, or something vain (bāthil), bāthil's behavior is reflected in the arrogance of the Western philosophical view of science which states the objects of that science as reality. Whereas the Islamic vision of reality and truth is a metaphysical survey of the visible or invisible world, including the perspective of life as a whole, both objective and subjective. ${ }^{55}$ Therefore, the subjective nature of science implies... that the human soul is creative, through the means of perception, imagination and intelligence, man participates in the 'creation' and interpretation of the world of

51 Naquib al-Attas, Islam and Philosophy, p. 27-28. There are three patterns of approach that are the strengths of the modern philosophy of science referred to in obtaining knowledge, namely: First, philosophical rationalism, which tends to rely only on reason without the help of experience or sensory perceptions. Second, secular rationalism, while accepting reason, tends to rely more on sense experience, denies authority and intuition, and rejects revelation and religion as the source of true knowledge. Third, philosophical empiricism or logical empiricism, which relies all science on observable facts, logic building, and language analysis.

52 Ibid., p. 34-40.

53 Ibid., p. 56.

54 Naquib al-Attas, Concept of Education, p. 49.

55 Naquib al-Attas, Prolegomena, p. 3. sense and sense experience, the world of shadows., and the world of incomprehensible forms. That is why subjective is not opposed to what is called objective, but is complementary to it. $^{56}$

When the conception of reality is interpreted as 'as it is' like the Western philosophy of science, this is the same as denying reality itself. This, of course, is incompatible with the Islamic world view. ${ }^{57}$ On that basis, unfortunately, the existing reality until now, what is considered objective is considered more real and therefore more valid than the subjective. So that the epistemology of natural science which is claimed to be more objective is considered to have higher validity than religious science, which is considered subjective. $^{58}$

Starting from the idea of the dichotomy of science between the objective and the subjective, Naquib sparked the idea of the epistemology of tauhid knowledge, which is an epistemology of science that seeks to unite the subjective and the objective, because in essence the two have complementary aspects. ${ }^{59}$ After all, it needs to be understood that science is unlimited because the object of knowledge has no limits. However, there is a limit to the truth in every object of knowledge, so that the search for true knowledge is not an endless search. If the search for knowledge was endless, then it would be impossible to attain knowledge in a span of time with a beginning and an end, and this would also render knowledge itself meaningless. ${ }^{60}$

The truth of a science is derived and absolutely belongs to

56 Ibid., p. 3-4. However, in the view of Islam that science is in the brain or in the soul (subjective), this should not lead to subjectivism, because God is the Real Source of Knowledge - which is free from doubt and confusion - is objective, that is, His Being. does not depend on human imagination. Because according to Naquib al-Attas human cognition is subjective and objective. This formulation reflects one aspect of understanding and application of the epistemology of tauhid.

57 Naquib al-Attas, Islam and Philosophy, p. 45, 53, 59-60. Because the study of nature, or whatever, on every object of knowledge in the created world. If the expression 'as is' is understood as something which is considered to be an independent reality, essentially or existentially - as if it were something that ends in and sustains itself - then such study loses its true purpose, and the search for knowledge becomes a deviation from the truth. Therefore, the validity of such knowledge can certainly be questioned, and fail to achieve certainty (yaqin), truth, and correct knowledge. Therefore, something as it is (that is, in essence) is different from itself, and that something different is what it means.

58 As explained by Naquib al-Attas in writing the history of Malay Islam, writers with Western minds think that local sources must be suspected because they are considered subjective and not completely objective. Because of this presumption, they leave the use of local sources at a disappointing level. Wan Daud, Philosophy and Practice, p. 295.

59 Naquib al-Attas, Prolegomena, p. 2 and 197. In this case Naquib often gives a parable that an architect will be able to be objective if he knows the house that has been designed, such as the shape, height, width, length of each part, as well as knowing the material and everything that is needed. However, the architect did not know the true state of the house before settling into the house. Only by living in the house can he find out which room is more comfortable at that time. This subjective judgment does not eliminate the external, objective aspect of the knowledge of the house. From this, Naquib also emphasized that there is no dichotomy between what is considered theory and practice, as well as between the objective and the subjective. See also Wan Daud, Philosophy and Practice, p. 296.

60 Naquib al-Attas, Islam and Philosophy, p. 63. 
the possessor of knowledge, however, human beings can subjectively understand science by using the three channels of validity (namely, the outer and bäthin senses, reason and intuition, and authority) in obtaining knowledge, this is simply -Eye on the mercy and grace of Allah SWT.

\subsubsection{Potential to Give Birth to the Exposition of Scientific Knowledge by the Qur'äni}

An idea of scientific knowledge is not born by itself, it requires extra-high work efforts to achieve it, especially since scientific knowledge has a correct and accurate exposition of the Qur'āni. To make this happen, one must engage deeply and reflect on the unity of the validity channel of science in its totality, namely the five senses, true news, common sense, and intuition combined with faith. ${ }^{61}$

One of the evidences of Naquib's exposition using the tauhid method has succeeded in finding the right date for the Trengganu Inscription which was previously a problematic in Malay history. ${ }^{62}$ And rejects Blagden's explanation that the seven hundred and two words inscribed on one part of the inscription can mean a fragment indicating a possible date. Based on this, [6] Blagden underlines that the exact date can only be determined in the future, because at the time of writing, scholars still do not know the condition of the Malay Peninsula in the 14th century which is associated with evidence of the arrival of Islam in the 13th century in the north. Sumatera. ${ }^{63}$

Examining the above thought shows that the channel of knowledge through empirical experience is indeed important and valid. However, it is not always correct and true by simply holding on to this empirical experience, that a truth is simply a relationship between propositions and empirical facts. Because the facts in science can be found, but the facts become false if put in the wrong place. ${ }^{64}$

From the above quotations, it is clear that Naquib puts forward the epistemology of monotheism in knowledge and

61 Ibid., p. 34-39. The channel of source validity and the epistemology of science referred to here refers to three sources based on the Islamic world view, namely: physical and mental senses, reason and intuition, and authority.

62 Syed Muhammad Naquib al-Attas, Islam in Malay History and Culture, (Bandung: Mizan, 1997), cet. II, h. 63-68. Using an analysis through the tauhid epistemological paradigm, Naquib al-Attas, rejects the opinion and conclusions of GWJ Drewes, regarding the dating of the Trengganu Parasasti, because this scholar cannot see the manuscript and only relies on his arguments on photography and Blagden's arguments made half a century ago. Therefore, without realizing it, his argument contains several errors. Furthermore, with Naquib al-Attas' caution in examining the manuscript itself, and supported by his knowledge and experience in Islamic calligraphy, Naquib immediately recognized the mistakes contained in the previous discussion in the matter.

63 Ibid., p. 5-7. If ignorance of the condition of the Malay Peninsula in the 14th century which is associated with evidence of the state of the late 13th century regarding the establishment of an Islamic empire in the northern part of the island of Sumatra, is the reason for the uncertainty regarding the exact date of the Trengganu inscription, we still cannot provide a reliable solution. positive, because we are in a state of ignorance and may continue to do so for a long time. However, this paper will show that this ignorance is not the main cause of failure to be positive about the dating of the Inscription, because although such ignorance also exists within me, I am still able to provide positive solutions to the problems it poses. See also Wan Daud, Philosophy and Practice, p. 302.

64 Naquib al-Attas, Islam and Philosophy, p. 56-57. education, in addition to combining it with intuitive media. For intuition is a legitimate and essential channel for acquiring creative knowledge, although it can also be accessed with certain ethical and intellectual preparations. ${ }^{65}$ So that the activities of reading, thinking, discussing with colleagues, contemplating, and praying are very useful because they prepare and activate the rational soul to achieve the meaning of something, and simultaneously the door to God's grace will open so that meaning will reach the soul.

That is why sincere purpose, moral integrity, contemplation or thought, and prayer are vital in seeking correct knowledge and understanding, thus giving birth to scientific exposition in the Qur'ân. Thinking is a spiritual process from the movement of the soul to meaning. ${ }^{66}$ And this process must be used correctly and appropriately, because it is a valid channel for the arrival of certain knowledge.

Based on these thoughts, combined with the historical philosophy he is engaged in, as applied to the study of the role of Islam in Malay history and culture, Naquib believes that... not all facts are important in understanding history, exactly the real fact that the wet pores on a woman's face was not important to someone who admired her beauty. From this it shows that it is very important for scientists to choose facts that are relevant and meaningful, because the meaning of a fact or something will only be true if it is coherent with the Islamic vision of reality and truth as projected by the conceptual system of the al-Qur'ān. ${ }^{67}$

Furthermore, by applying the epistemological principles of monotheism, Naquib has the courage to dismantle all layers of argumentation and examine the vague claims of adherents of the transcendent unity of religion. Because there is no transcendent unity of religions, if what is meant by unity is oneness or samenes, because all religions in this world are clearly not the same. ${ }^{68}$

Likewise, Naquib attacks the possibility of understanding unity as interconnection between various religions at a transcendent level, because by doing so, it means that every

65 Naquib al-Attas, Prolegomena, p. 238. Intuition media, in fact, was applied by many previous Muslim intellectuals in their search for and finding the correct knowledge. such as the admission of Ibn Sina (370-428 H / 980-1037 AD) that all knowledge of reality and truth and the actual projection of the highest nature of things initially appears through the medium of intuition. Even knowledge of comprehensible truths (mafhüm) ultimately derives from intuitive principles.

66 Ibid., p. 124. Thinking is the soul's movement towards meaning and this process requires imagination (al-khayal). Intuition, both in terms of intelligence (al-hadd) and in terms of enlightenment or illuminative experience (al-wijdan) is the arrival of the soul in meaning or the arrival of meaning into the soul, either by searching through evidence, as in the second case, or by means of given by Allah Most High, as in the first case. The meaning of the first and second cases, in this case, is related to the acquisition of knowledge, which according to Naquib alAttas is divided into two kinds. The first is knowledge given by Allah Most High, as His gift to humans, and the second is knowledge that is attained and obtained by a human being based on his own mental effort which comes from the experience of life of the physical senses and vows and attention, investigation, and study. See also Naquib al-Attas, Islam and Philosophy, p. 78-80.

67 Naquib al-Attas, Islam and Philosophy, p. 51; Naquib al-Attas, Concept of Education, p. 57.

68 Naquib al-Attas, Prolegomena, p. 7. 
religion in this world is by itself incomplete, and therefore unable to submit to God. The Almighty correctly and precisely. $^{69}$

Therefore, that at the transcendent ontological level, God should be known as Rabb (creator God) by all beings, but not necessarily known and worshiped as Ilāh. Even at this level there are still errors and falsehoods, as in the case of devils. If what is meant by 'transcendent' refers to an ontological condition, God is not a religious God (i.e. Ilāh), as is understood in the alleged existence of something called 'the unity of religions at that level.' At that level, God is recognized as Rabb, not as Ilāh. As for God as Rabb, it does not necessarily imply Oneness and equality in proper recognition of the truth known to him, because the devil also knows God as Rabb, but does not acknowledge him correctly. $^{70}$

On the basis of this thought, it can be said that the unity that might occur is if the transcendence refers to the psychological level, not at the religious level, but in the religious experience of a few people (certain selected people), which is not the goal of religion. ${ }^{71}$

Thus, it can be concluded that the transcendent level of religious experience is not generally the goal of religion. It is a level of religious experience for certain humans, who have a high capacity for enlightenment of the spiritual soul (spiritual substance) on the basis of the grace of Allah SWT.

Therefore, against the view that all religions are equal and perfect, Naquib's analysis rejects this, because if it is assumed that each religion is self-perfect and has the same truth and validity. In fact, the unity does not refer to religions, but to God and those religions at the ontological transcendent level. Even so, for Naquib, these religions are still not the same and perfect, because at the transcendent ontological level there is a tendency that at that level (transcendent) there is a refusal to accept God correctly, from which it originates.

$69 \mathrm{Ibid}$., p. 8. There is no 'transcendent unity of religions,' if what is meant by 'unity' is 'wholeness / oneness' and 'equality,' and if what is meant by 'unity' is not 'wholeness / oneness' and 'equality,' meaning there is a plurality or inequality of religions at the transcendent level. Furthermore, if it is accepted that there is a plurality or inequality at the transcendent level, and the 'unity' that is meant is 'the interrelation of the parts that make up the whole' so that the unity that is meant is the interrelation of plurality and inequality of religions as parts that make up the whole. Consequently, at the level of ordinary existence, in which man is bound by the limitations of his humanity and material nature, any religion is by itself imperfect, is not sufficient to realize the goal of his religion, namely the true surrender of oneself to the One Universal God without associating Him with friends, foes, or the like on a transcendent level. However, what religion means here is to realize its goal at the level of existence, in which humans are bound by the limitations of their humanity and material nature, not when humans are no longer bound by boundaries as expressed by the term "transcendent."

70 Ibid., p. 8-9.

71 Ibid., p. 9-10. If what is meant by 'transcendent' refers to a psychological condition at the level of experience and consciousness that 'transcends' or 'crosses' the level of the common man..., the 'oneness' experienced and making him aware at the transcendent level is not religious unity, but a unity of experience. and religious consciousness...(i.e. consciousness) experienced by only a few individuals. However, religion is meant for human life in general, and humans as a whole cannot possibly be at a transcendent level because there will be religious unity at that level. disobedient, arrogant, and wrong behaviors. ${ }^{72}$

On another occasion, in connection with scientific exposition and applying the epistemology of tauhid. Naquib criticized some Muslims for issuing fatwas that alcohol is haram. This opinion is neither correct nor correct, [17] if the person issuing the fatwa knows the dialectic of theology and understands the correct logic. ${ }^{73}$ Including Naquib's rejection of the opinion that says life insurance is haram, if you use the reason that it approaches gambling (al-maissir). ${ }^{74}$

Due to some of Naquib's objections to some of the above, this points to the importance of a precise definition, which Muslim scholars seem to have failed to make somewhat. Moreover, some opinions that reject Sufism have developed due to glaring mistakes made by individuals who call themselves Sufi groups. Naquib strongly questions the validity of this argument by saying that one cannot deny the

72 Ibid., p. 9. If it is denied that the unity at that level is the interrelation between plurality and inequality of religions as parts that make up a whole, it can be said that each religion at the level of ordinary existence is not part of a whole, but a separate whole. The 'unity' that is meant is not the 'unity' or 'equality' of religion, but the unity of the God of religions at the transcendent level... (but)... God at that level is understood as $R a b b$ not as the Ilāh of the revealed religion. And recognizing God as $R a b b$ does not necessarily mean... complete surrender... for iniquity, pride, and guilt originate on the same transcendent level.

73 Quraish Shihab, Tafsir Al-Mishbah: Message, Impression and Harmony of AlQur'ān, (Jakarta: Heart Lantern, 2006), cet. VII, vol. 3, h. 192-193. See Wan Daud, Philosophy and Practice, p. 308. Whereas what is prohibited by al-Qur'ān is al-khamr, which is a type of drink containing alcohol. But if alcohol is used other than for drinking, there is no prohibition against using it. Moreover, if it is seen from the origin of the Arabic language regarding the type of drink (al-jins), it seems that it does not include alcohol. Because in this type of drink (al-jins) there is a species called al-khamr, and this al-khamr is explicitly forbidden in the Qur'an. As a result of the opinion that prohibits alcohol, there are many problems that occur in Muslim communities, because alcohol is widely used in anesthesia, cosmetics, liquid medicine, and tablets. Likewise, Quraish Shihab's interpretation of QS. al-Māidah: 90-91 There are differences of opinion among the scholars, but in turn, based on the agreement of the majority of scholars, that khamr is forbidden in its use as a good drink, a little or a lot. The reference is based on the hadith of the Prophet. which means: "Everything that is intoxicating is khamr, and every khamr is haram." (Narrated by Muslim from Ibn Umar). Also based on the hadith of the Prophet. which means: "Anything that is intoxicating if you drink a lot, then the least amount is haram." (Narrated by Ibn Majah through Jabir Ibn Abdillah). that khamr is forbidden in its use as a good drink, a little more than a lot. The reference is based on the hadith of the Prophet. which means: "Everything that is intoxicating is khamr, and every khamr is haram." (Narrated by Muslim from Ibn Umar). Also based on the hadith of the Prophet. which means: "Anything that is intoxicating if you drink a lot, then the least amount is haram." (Narrated by Ibn Majah through Jabir Ibn Abdillah). that khamr is forbidden in its use as a good drink, a little more than a lot. The reference is based on the hadith of the Prophet. which means: "Everything that is intoxicating is khamr, and every khamr is haram." (Narrated by Muslim from Ibn Umar). Also based on the hadith of the Prophet. which means: "Anything that is intoxicating if you drink a lot, then the least amount is haram." (Narrated by Ibn Majah through Jabir Ibn Abdillah).

74 Wan Daud, Philosophy and Practice, p. 308. Whereas gambling must have several characteristics which are not the same as insurance characteristics. Gambling must have win and lose, occur over a period or a certain time, be it a number of hours, how many days, or a maximum of several weeks, and should increase feelings of excitement that are excessive to cause addiction. Because it does not have characteristics like those found in gambling, insurance should not be considered the same as gambling even though it is still not allowed for other reasons. QS. al-Baqarah: 219, QS. al-Māidah: 90-91. From this context, Naquib makes clear the importance of a precise definition, which Muslim scholars seem to have failed to make. 
benefits of a knowledge only because of the mistakes made by its practitioners and those who acknowledge it as its practitioners. $^{75}$

Furthermore, Naquib points out that there are some contradictory Muslim political leaders, who claim to have the right to issue official arguments on religious issues because of what the ulama do, even though they do not have authority in religious matters. At present, if the scholars who have studied at least a certain discipline make mistakes, politicians who admit and are clearly ignorant (regarding religion), of course, more often than not, commit innumerable and immeasurable fundamental mistakes. ${ }^{76}$

In relation to education, it is often found that today's politicians and technocrats have often made signals about the importance of creativity with education, even though they do not understand the correct and correct concept of education. ${ }^{77}$ In essence Naquib does not reject the importance of training and development of that human aspect - sensory imagination (sensitive) - in education, but it must be the result of the development of the previous cognitive imagination, if it is not the result of developing cognitive imagination, the training and development creativity will become rough, wild., and tragic. Because what is called development in the Islamic concept is the integration between the spirit of cognitive imagination and sensory imagination, which is seen from various religious works and is driven by religious zeal, in the supernatural culture of the eternal and weighty past. ${ }^{78}$

Thus it can be understood that the development of creativity for someone can only be seen from the combination of cognitive imagination and sensory imagination in an integrated manner. This conception seems different from the current condition of education, where development is more directed towards social, economic, cultural, environmental and welfare aspects, rather than spiritual health.

Starting from the above understanding, it cannot be denied the importance of tauhid epistemology in education today, as an effort to integrate aspects of sensory imagination and

75 Ibid., p. 309. If wrong assumptions like the one above are allowed and even regarded as something that is principle, then all valid knowledge will also be rejected, because in various kinds of sciences, such as fiqh, theology, philosophy, and economics there is also fraud, misinterpretation, and misrepresentation. People should not refuse knowledge just because a few people who are called scholars make mistakes.

76 Ibid., p. 310.

77 Naquib al-Attas, Prolegomena, p. 154. Regarding the importance of creativity in the educational process, it is indeed important, but it is very unfortunate, if what is recognized and considered an understanding of one's activities can be called creative only comes from sensory imagination related to technology, arts, and handicrafts. So that creative thinking lessons in schools are limited to problems related to technology. Creative writing courses in higher education are also limited to issues related to fiction writing. Scientific works that are accurate are not considered creative. For Naquib al-Attas, like technology, as well as art, is a product of the soul's imagination which is sensory (sensitive), not imagination which is cognitive in nature. While the cognitive imagination has been forgotten by politicians and educational experts, in some Muslim societies, they 'know and acknowledge' scientific activity halfheartedly. See also Wan Daud, Philosophy and Practice, p. 309.

78 Ibid., p. 155. cognitive imagination in educational practice. Moreover, [13] the fact that Islamic education that has been going on so far tends to emphasize a naturalistic-positivistic approach by prioritizing purely coherence-cognitive aspects. ${ }^{79}$ Where the main indicator of this approach is only limited to the ability of students to be able to answer questions about religious knowledge without touching the practical aspects of morality. Even at a further stage, [14] Islamic education is directed at aspects of textual correspondence which emphasize the ability of students to memorize existing religious texts. ${ }^{80}$

Therefore, by applying the principles of monotheistic epistemology in education, it can integrate aspects of sensory imagination and cognitive imagination in an integrated manner, which has the potential to give birth to an exposition of scientific knowledge in the Qur'āni manner. Besides having the potential to be an accomplished writer and not a rewriter, and able to combine theory and practice.

\section{Conclusion}

Based on the description above, the following conclusions can be drawn, namely: First, the birth of the epistemological principles of Islamic education, the tauhid paradigm, is based on the conceptions of $a d a b$ and $t a^{\prime} d i b$ as the correct and correct terms in Islamic education. This shows that Naquib's thought in the meaning of tauhid is not limited to the theocentric dimension alone, but develops in the meaning of the anthropocentric dimension, especially in education and science.

Therefore, Naquib put forward the idea of the importance of the epistemological principles of tauhid to be applied in the Islamic education system. This effort was made to revive (revitalize) the concept of tauhid in education that is unique to Islam, and to change the way the world viewpoint is focused on the ultimate absolute reality and truth, namely Allah SWT., and that only exists in ad-dīn, namely Islam.

In addition, in turn it is operational as an effort to be able to develop a better Islamic education in the future. Without implementing the epistemological principles of tawhid in Islamic education, it is very possible that the process of Islamic education as $a d a b$ and $t a^{\prime} d i b$ cannot take place properly and correctly. This is because the concept of Islamic education as $a d a b$ and $t a^{\prime} d i b$ has an integral link with the epistemological principles of tauhid in its operation. Moreover, [12] the fact that is currently happening is assumed by educational figures that Islamic education that takes place in Indonesia is just a name. ${ }^{81}$

79 Gerard Radnitzky, Contemporary schools of metascience: Anglo saxon schools of metascience, continental schools of metascience, 2nd Edition (Goteborg, Sweden: Akademiforlaget, 1970), p. xxxv-xxxx.

80 Fazlur Rahman, Islam (Chicago, US: The University of Chicago Press, 1979), p. 191.

81 Abudin Nata, Social History of Islamic Intellectuals and Educational Institutions, (Jakarta: RajaGrafindo, 2012) p. 5. It must be recognized that there are differences and similarities between Islamic and Western epistemologies. Islam recognizes that there are sources of knowledge that come from natural phenomena and thoughts as found in the West in positivism and rationalism. However, in Islam the source of knowledge that has the highest authority comes 
Admittedly or not, it turns out that one of the core causes of error in problems in education today lies in the absence of $a d a b$. So that the result is confusion, error, and ignorance that continues (read: prolonged) at various levels of community leadership. If classified first, confusion and misperception about science, which in turn creates; second, the lack of courtesy of society, and the consequences of the first and second points are; third, [16] the emergence of leaders who are not only unfit to be leaders of the $u m m a h,{ }^{82}$ but also lack high morals and sufficient intellectual and spiritual capacities, which are indispensable for Islamic leadership. ${ }^{83}$

Second, the implication of the first conclusion above is that at least five principles of tauhid epistemology in Islamic education in this paper can be embodied in the Islamic education system in the future, namely as follows: First, the values of tauhid epistemology have the dimensions of alQur'ān in a diametric way, not speculative thinking. Second, put forward the significance of spiritual substance. Third, the epistemological values of tawhid are the unification of the religious and the scientific. Fourth, minimizing the problematic dichotomy between objective and subjective science. Fifth, it has the potential to give birth to scientific exposition of scientific knowledge according to the Qur'āni.

Of course, the five principles of tauhid epistemology put forward by the author above can be of concern to all components involved in the development of Islamic education thought treasures, so that the direction of developing Islamic education will reach an optimal target point. If possible, with the support of various parties, it can be implemented in the system and process of Islamic education in Indonesia in the future. So that this paper has a contribution to the treasury of the development of Islamic education in Indonesia. In turn, by the grace of Allah SWT., the results of the process of Islamic education in Indonesia will be able to lead to the achievement of complete human beings (al-insānul kāmil) in building Islamic civilization and reaching the highest peak of glory and regaining the golden age, In Syā Allāh. Such a goal, is the true essence of the meaning of khalifah fil ardhi, the next generation as representatives of Allah on earth. Amīn Yä Rabb al-'Älamīn.

\section{References}

[1] Al-Qur'ān al-Karīm, Mushaf Lafziyyah Al-Hudā; Al-Qur'ān Translated by Word; equipped with Thematic Verses and AlHadīs., Jakarta: Al-Qur'ān Translator Organizing Foundation; Al-Huda Gema Insani, 2009.

from revelation (al-Qur'ān) and hadith, as well as from self-cleansing (bāthin) and intuition. In other words, the sources of knowledge in Islam are far more complete than the sources of knowledge as understood by the West.

${ }^{82}$ Komaruddin Sassi, Ontology of Islamic Education Paradigm Tauhid Syed Muhammad Naquib Al-Attas: Revitalization of Adab-Ta'dib in Education, (Jakarta: Prenada Media Group, 2020), p. 136-137 \& 174. Ummah is all citizens of the nation who believe in Islam and in one God throughout the world are members of the Islamic community.

83 Naquib al-Attas, Treatise for the Muslims, p. 44-47. See also Naquib al-Attas, Islam and Secularism, p. 18.
[2] Al-Attas, Syed Muhammad Naquib., Islam and Secularism, trans. Karsidjo Djojosuwarno., Bandung: Pustaka Salman ITB, 1981.

[3] Al-Attas, Syed Muhammad Naquib., The Concept of Education in Islam: A Framework for the Development of the Philosophy of Islamic Education, trans. Haidar Baqir, from the original title The Concept of Education in Islam: A Framework for an Islamic Philosophy of Education., Bandung: Mizan, 1984.

[4] Al-Attas, Syed Muhammad Naquib., Islam and Philosophy of Science, trans. Saiful Muzani, from the original title Islam and the Philosophy of Science., Bandung: Mizan, 1995.

[5] Al-Attas, Syed Muhammad Naquib., Prolegomena to The Metaphysics of Islam An Exposition of The Fundamental Elements of The Worldview of Islam., Kuala Lumpur, Malaysia: ISTAC, 1995.

[6] Al-Attas, Syed Muhammad Naquib., Islam in Malay Culture and History., Bandung: Mizan, 1997.

[7] Al-Attas, Syed Muhammad Naquib., Treatise for Muslims., Kuala Lumpur: ISTAC, 2001.

[8] Al-Ghazali, Revealing the Secret of Qalbu: Efforts to Get Closer to the Presence of the All-Knowing All that is Unseen, trans. Bahrul Abubakar, from the original title Mukāsyafatul Qulūb al-Muqarribu ila 'Allāmil Ghuyūb fi' Ilmi alTashawwūf., Bandung: Nansa Aulia, 2008.

[9] Khaldun, Ibn., Muqaddimah, trans. Ahmadie Thoha., Jakarta: Pustaka Firdaus, 1986. Khamere'i, Ali., Ali Shari'ati and Murtadha Muttahari, Muhammad Iqbal in the View of Shiite Thinkers, trans. Andi Haryadi, from the original title Iqbal Manifestation of the Islamic Spirit., Jakarta: Islamic Center, 2003.

[10] Mohd, Wan Nor Wan Daud., Philosophy and Islamic Education Practices Syed Muhammad Naquib Al-Attas., Bandung: Mizan, 1991.

[11] Muttahari, Murtadha., Introduction to Islamic Epistemology., Jakarta: Shadra Press, 2010.

[12] Nata, Abudin., Social History of Islamic Intellectuals and Educational Institutions., Jakarta: RajaGrafindo, 2012.

[13] Radnitzky, Gerard., Contemporary Schools of Metascience: Anglo Saxon Schools of Metascience, Continental Schools of Metascience, 2nd Edition., Goteborg, Sweden: Akademiforlaget, 1970.

[14] Rahman, Fazlur., Islam, Chicago, US: The University of Chicago Press, 1979. Rosadisastra, Andi., Method of Interpretation of the Verses of Science and Social., Jakarta: Amzah. 2012.

[15] Sina, Ibn., Kitab al-Najaf, ed. Majid Fakhri., Dar al-Afaq alJadidah, Beirut, 1985.

[16] Sassi, Komaruddin., Ontology of Islamic Education Paradigm Tauhid Syed Muhammad Naquib Al-Attas: Revitalization of Adab-Ta'dib in Education., Jakarta: Prenada Media Group, 2020.

[17] Shihab, Quraish., Tafsir Al-Mishbah: Message, Impression and Harmony of Al-Qur'ān., Jakarta: Heart Lantern, 2006.

[18] Umar, Nasaruddin., Method of Interpretation of the Verses of Science and Social, in Andi Rosadisastra, (Jakarta: Amzah. 2012), cet. III, p. x-xi. 